\title{
Cuatro años a bordo de mí mismo: viaje de Eros y Thanatos
}

\author{
Cuatro años a bordo de mí mismo: Journey of Eros and Thanatos
}

\author{
Abad Castañeda Borrero \\ Universidad Surcolombiana, Colombia \\ abad_cabo@yahoo.com
}

"Sí, el amor es una flor de sangre"1

De acuerdo a las teorías de Freud y otros reconocidos estudiosos del comportamiento humano; en la vida de éste, dos elementos se conjugan y confunden permanentemente: el Eros y el Thanatos; los dos, procedentes de la antigua mitología griega, que en apariencia parecieran ser contrarios -pues Eros representa todos los impulsos que nos mueven a la vida, a la creación $\mathrm{y}$ al amor; $\mathrm{y}$ Thanatos la fuerza que nos impele a la muerte, a la destrucción y al odio- pero que en realidad viven en permanente abrazo, los dos se estrechan y hacen presencia en la vida cotidiana del ser humano. Eros y Thanatos; amor y muerte; conviven en un constante movimiento pendular que va de lo más sublime a lo más horrendo; de la suprema dicha, al dolor más intenso: “La muerte es inseparable del placer, Thanatos es la sombra de Eros. La sexualidad es la respuesta a la muerte. Desviado de la reproducción, el erotismo crea un dominio aparte regido por una deidad doble: el placer que es muerte" ${ }^{\prime 2}$. Y si es esa duplicidad divina y diabólica la que gobierna nuestras vidas; también es ella misma la que encontramos en la literatura de todos los tiempos y lugares del mundo, que no es otra cosa que la profunda y auténtica revelación de la vida de los hombres que poblamos este planeta.

Una muestra ejemplar del abrazo de Eros y Thanatos es sin ninguna duda, la novela Cuatro años a bordo de mí mismo, del escritor bogotano Eduardo Zalamea Borda, obra que narra el viaje de un joven de 17 años, desde Bogotá hasta la Guajira. Viaje que puede leerse desde dos puntos de vista: en primera instancia se trata de un viaje real donde el personaje, a través de una sensibilidad exacerbada de sus sentidos (vista, gusto, oído, olfato y tacto), presenta en un lenguaje altamente poético la realidad tangible que va desde la fría y oscura Bogotá de los años 30 del siglo XX; hasta los lugares más abrazantes y paradisiacos de la lejana Guajira. En segunda instancia, el viaje físico se puede ver como un pretexto que le permite al personaje narrador emprender un profundo viaje de introspección; no gratuitamente la novela se llama Cuatro años a bordo de mí mismo; y a manera de subtítulo: Diario de los 5 sentidos.

Existe una perfecta correspondencia entre el viaje físico -que no es otra cosa que el mito del eterno retorno hecho realidad, pues desde el momento en que el personaje decide partir hasta en el que decide regresar, lo asalta siempre la nostalgia de su ciudad natal perdida- y el viaje interior que le permite al poeta incursionar hasta lo más profundo del ser y descubrir los sentimientos más sublimes y más nefandos de su alma; sentimientos que el poeta deja aflorar como fuente diáfana a través de su fluir de consciencia: "He dicho que soy perezoso e inerte. Es uno de los muy pocos defectos que me he encontrado, aunque siempre he deseado tener muchos. Es la mejor manera de vivir. Y si a los defectos se añade un vicio ya está hecha la fortuna" ${ }^{\prime 3}$. El viaje espiritual también es de ida y regreso, pues al final, el poeta descubre que el viaje al interior de su alma le permitió conocerse más a sí mismo;

1 PAZ, Octavio. La llama doble. Amor y erotismo. Bogotá: Seix Barral, 2004, p. 211.

2 Ibíd., p. 161.

3 ZALAMEA BORDA, Eduardo. Cuatro años a bordo de mí mismo. Bogotá: El Tiempo, 2003, p. 19. 
la voz interior del poeta le habla a él mismo: "Yo también me oigo a mí mismo ahora, entre la noche y el viaje" ${ }^{4}$. Y el poeta le responde, “ ¡He oído, he gustado, he olido, he tocado, he visto, he sufrido, he llorado, he copulado, he amado, he reído, he odiado y he vivido!" 5 .

Se observa a través de esta enumeración, los diferentes sentimientos que experimentó el poeta, desde el amor hasta la muerte. El amor siempre de gancho con la muerte. Este viaje de introspección, también le permite al poeta expresar el cansancio y aburrimiento que le genera la falsa y timorata sociedad bogotana de finales del XIX y principios del XX; que equivocadamente la tradición conservadora dio en llamar la "Atenas Sudamericana". El poeta percibe la chatura de una ciudad con pretensiones de gran Urbe, pero que en realidad no pasa de ser un puebluco de gentes antipáticas que sólo leen obras estúpidas y acarameladas: "Me aburría profunda y concienzudamente en esa corta ciudad, leyendo libros estúpidos y acaramelados de Ricardo León, Jorge Oneth y Henri Bordeaux. No llegaban libros de otros autores y todos los ciudadanos se creían grandes poetas y literatos"6.

Además, el poeta critica mordazmente la pacatería y lujuria de la sociedad de la época que predica la moral y la justicia, pero que se esconde para fornicar, mancillar, robar y asesinar, y cuando aún su aliento huele a alcohol y su carne a sexo, gritan improperios contra el borracho y el lúbrico.

Justamente, fruto del flato y aburrimiento que le causa la sociedad, el poeta decide emprender el viaje como forma eficaz de escapar de la cárcel social de su tiempo; en este sentido, el viaje se convierte en una especie de fuga: "Pero no existe un espectáculo tan decididamente divertido que pueda curar el aburrimiento perenne y un día resolví irme. Sin saber a dónde. Yo no sabía para dónde irme. Pero eso no importaba. Lo único necesario era salir de allí"7. Una vez en la Guajira y luego de innumerables aventuras y sensaciones que enriquecen la vida personal del poeta, éste establece diferencias sustanciales entre la vida moderna de Bogotá y la primitiva de la Guajira, aquélla, llena del humo de las fábricas y de los carros; y ésta, profusa en olores, sonidos y colores naturales y auténticos. Aquí está la verdadera vida, dice el poeta, allá la falsedad y el engaño.

Consecuencia también del aburrimiento, se despierta en el poeta un verdadero sentido de trashumancia que lo lleva sin rumbo de un lado para otro; no se apega a nada ni a nadie; su destino está en todas partes, está donde sus pies lo quieran llevar; y unido a la trashumancia el poeta experimenta sincero dolor por la orfandad y soledad infinita como si Dios hubiera muerto: "El silencio es tan grande que parece que Dios hubiera muerto. $\mathrm{O}$ estuviera construyendo otro mundo" ${ }^{\prime \prime}$. La soledad y el desamparo desgarran el alma no sólo del poeta sino de todos los personajes de la novela, al grado de crear un vacío que los incapacita para amar.

Los temas de la soledad y la orfandad recurrentes a lo largo de la novela se encuentran en perfecta concordancia con la soledad interior del poeta que se siente vacío y desamparado desde la niñez.

Finalmente, cuatro años fueron suficientes para que el poeta realizara ese viaje circunvalar de doble sentido: el físico que lo saturó de abundantes experiencias que, aunque ricamente eróticas, fueron tristemente trágicas; y el introspectivo, que le posibilitó incursionar a través de todos los caminos y vericuetos de su alma. Si el viaje físico le mostró diversos lugares con sus formas, colores y matices lo mismo que las variadas culturas con sus alegrías y dolores; el viaje espiritual

4 Ibíd., p. 304.

5 Ibíd., p. 307.

6 Ibíd., p. 19.

7 Ibíd., p. 20.

8 Ibíd., p. 169. 
le mostró las diversas tonalidades de su alma donde se abrazan siempre ángeles y demonios. El viaje de ida y retorno de Ulises duró veinte años; el del poeta de la novela en estudio, cuatro.

De otro lado, tanto el viaje físico como el espiritual le permiten al poeta tener una clara percepción de la fugacidad de la vida, él descubre que si 20 años -como en el tangono son nada, menos lo son cuatro. La vida es efímera y muy pasajera, y el tiempo nos marca con huellas visibles en todo el cuerpo: "Pero la vida pasa pronto. Pasa sobre nosotros, con los finos cuchillos que hacen las sutiles arrugas de los rostros. Y pasa con el blanco cinc para las canas, derramando a poquitos, con pinceladas ligeras, comenzando por las sienes. Va arrancando de los ojos el brillo y lo cambia por la opacidad que guarda en pomos que nadie ha visto" ${ }^{\prime 9}$. Además, en la sensación de fugacidad de la vida, el mañana y el ayer son absurdos porque no existen; el ayer murió y sólo vive pegado en el recuerdo; el mañana es la esperanza de vivir y la certeza de la muerte. Sólo existe el hoy, el ahora, que es la vida que camina hacia la muerte.

El viaje como tema universal de la literatura, aparece en Cuatro años a bordo de mí mismo, como palo mayor, donde se anudan los demás temas que aborda la novela; entre otros: el amor, la muerte, la vida, la tragedia, la naturaleza. Este último en parentesco con el ser humano:

La idea de parentesco de los hombres con el universo aparece en el origen de la concepción del amor. Es una creencia que comienza con los primeros poetas, baña a la poesía romántica y llega hasta nosotros. La semejanza, el parentesco entre la montaña y la mujer o entre el árbol y el hombre, son ejes del sentimiento amoroso. El amor puede ser ahora, como lo fue en el pasado, una vía de reconciliación con la naturaleza. No podemos cambiarnos en fuentes o encinas, en pájaros o en toros, pero podemos reconocernos en ellos ${ }^{10}$.

9 Ibid., p. 52.

10 PAZ, op. cit., 217.

11 ZALAMEA, op. cit., p. 22.
Justamente, Cuatro años abordo de mí mismo, está en perfecta consonancia con lo planteado por el poeta mexicano, pues a través de la mirada del poeta narrador de la novela, las montañas, las llanuras, los prados, el mar, la sal, el viento y en general toda la naturaleza agreste de la tierra guajira, cobra una abrumadora fuerza humana y de manera particular, femenina. Así entonces, las colinas se perciben como los hombros redondos y torneados de la mujer; las llanuras se asimilan a su vientre cálido, fecundo y perfumado; los hirsutos valles a sus axilas: "La tierra va tomando -con el calor- la movilidad del cuerpo femenino y su gracia. Son colinas redondas y torneadas como hombros, las que hay en el fondo del paisaje. Onduladas llanuras, de donde surgen cálidos perfumes como vientres femeninos. Valles penumbrosos, redondos, herbosos como las axilas. El aire está cruzado por el beso de las flores que se fecundan"11.

Lo mismo sucede con el nombre de Riohacha, nombre híbrido que el poeta descompone e invierte cargándolo de valores eróticos; el río que es sustantivo de género masculino se vuelve femenino, porque es dulce y suave, su caricia es delicada y perfumada; y el hacha, sustantivo de género femenino se vuelve instrumento viril porque es quien asesta el golpe certero y violento que penetra y desgarra.

De la misma manera, el mar y todos los elementos que le son afines -barcos, velas, sal, olas, mástiles, peces etc.-, aparecen poéticamente asociados tanto a las partes físicas como a los diferentes estados anímicos y emocionales de la mujer. De esta manera, el mar multicolor, suave y sonoro, repentinamente puede cobrar la fuerza violenta y seductora de la mujer. Este mar, como la mujer, puede amar, odiar, matar o seducir. Él se bambolea, se mueve de un lado para otro con ritmos voluptuosos como los de la mujer al caminar; sus olas forman curvas ricas y sensuales que invitan al goce. Pero ese erótico mar femenino también posee la fuerza 
destructora de la mujer enfurecida: "Había cambiado su verde de infancia, de ternura, ese verde casi blanco, que molestaba a los ojos y los hería como la luz de los sopletes eléctricos, por un verde profundo, denso, oscuro, de ojos de mujer mala"12. No obstante, el poeta ama inmensamente el mar, como se ama a la mujer, pese a que aquél como ésta no le dan la seguridad de ser correspondidos: "El mar, este mar que yo amo como a una mujer demasiado bella y demasiado grande, que me da la seguridad de no ser correspondido" ${ }^{\prime 13}$.

El intenso amor que el poeta siente lo lleva a ver en la naturaleza el objeto amado, al respecto Octavio Paz afirma: "Por esto, las imágenes poéticas trasforman a la persona amada en naturaleza -montaña, agua, nube, estrella, selva, mar, ola- y a su vez la naturaleza habla como si fuese mujer"14.

A lo largo de la novela es recurrente la asociación de todo lo marino con la sensualidad femenina; obsérvese cómo magistralmente el poeta logra comparar la mujer con las velas del barco que se contonean, que se hinchan y se mueven rítmicamente con el soplo viril del viento. Las velas son la metáfora de la mujer y el viento la del hombre; el viento penetra e hincha las velas moviéndolas siempre eróticamente; las velas henchidas son la gravidez del viento y la mujer la gravidez del hombre: "Las mujeres... todas son dúctiles y frescas como un rumor de velas al viento"15. “... las velas están tensas, hinchadas como un grávido vientre"16. Pero el viento también se invierte y se vuelve femenino para mostrar el lado oscuro de la mujer; porque así como ésta es dadora de vida, también lo es de muerte. Ella prodiga dulzores y encantos, pero también engendra dolores y pesares; Eros, la fuerza que empuja a la vida se abraza con Thanatos que empuja a la muerte. El viento es comparado con la mujer porque-dice el poeta-ni en él ni en ella se puede confiar, son cambiables, guardan siempre sorpresas insospechables: "Pero es necesario -y lo digo aunque sea muy viejo y repetido- desconfiar de los vientos y de las mujeres. Lo rigen manos caprichosas y las gobiernan sutiles intenciones y desconocidos propósitos. No tienen libertad. No dependen de sí mismos. Pero a ellos, como a las mujeres es necesario amarlos por sus perfumes y por su dulzura"17. Abrazo perfecto de Eros y Thanatos. Se rechazan pero se atraen, se odian en el amor y se aman en el desprecio. Las fronteras entre el amor y el odio se vuelven invisibles, se difuminan en atmósferas de humo sin que se descubra en qué momento se pasa del uno al otro; Freud así lo anota: "Por medio de este enlace de la libido con la crueldad se produce también la mudanza de amor en odio, de mociones tiernas en mociones hostiles"18.

De la misma manera concibe Lou AndreasSalomé la lucha atávica del amor entre los sexos, donde se juntan dos contrarios que jamás se parecen, pero que viven siempre juntos: "No es casual que en unas mismas circunstancias puedan darse odio y amor, que ambos sean genuinamente fases de una misma tormenta de pasiones" ${ }^{19}$.

También para Dick, marinero ya viejo, amigo del poeta, la percepción acerca de la mujer es trágica y por eso no las ama. Prefiere amar el mar, pero para amarlo hay que ser puro y no haberse contaminado con las mujeres, porque ellas son como el filo de las algas, y cortantes como los sargazos: "Ellas son semejantes -las mujeres- en su dulzura pegajosa al filo de las

12 Ibíd., p. 26.

13 Ibíd., p. 46.

14 PAZ, op. cit., p. 220.

15 ZALAMEA, Op. Cit., p. 15.

16 Ibíd., p. 80.

17 Ibíd., p. 50.

18 FREUD, Sigmund. "Tres ensayos de teoría sexual". En: Obras completas. Tomo VII. Buenos Aires: Amorrortu, 1995, p. 152.

19 SALOMÉ, Lou Andrea. Erotismo. Palma de Mallorca: El Barquero, 2003, p. 48. 
algas, y al borde cortante de los sargazos" ${ }^{20}$. Además, dice Dick, sus besos dejan en la boca un sabor amargo y doloroso. Para este viejo marinero, el mar condensa la sensualidad femenina porque le posibilita el recuerdo de la infancia junto al abrigo materno. Ama el mar porque se siente engendrado y nacido en él: "Yo lo amo, con un amor sexual, que mira senos en cada onda y sirenas en cada curva, porque fue lo primero que vieron mis ojos allá en mi tierra...En Wilhelmstadl mi boca supo de la sal del mar en los senos redondos de mi madre" ${ }^{21}$.

El mar para el poeta, más que un lugar o un espaciofísico, es un ser bellísimo, inconmensurable, lleno de vitalidad y misterios, para él es lo más grande que existe en el mundo.

El amor asociado a las mujeres está entrelazado todo el tiempo con la tragedia, Eros y Thanatos se funden en un eterno abrazo de amor y muerte; el amor que desea siempre la vida, también engendra la muerte. Alegría y dolor; risa y llanto aparecen siempre hermanados; han nacido aunque diferentes y opuestos siempre juntos y complementarios: “¿Quién creyera, que eso tan suave, tan dulce que es un beso, tiene (sic) una tremenda fuerza destructora?"22.

En la Guajira el poeta experimenta el placer y el dolor, la felicidad y la tristeza; pero sobre todo el deseo incontenible de la carne que pide a gritos el abrazo. Todas las mujeres convidan al goce, todas rebozan de sensualidad: “¿Qué bella! Geométricamente perfecta, con su manta que la desnuda y la boca roja, tensa, ceñida, apretada en un imaginario mordisco... senos temblorosos y duros, que perfuman la noche ¡cabellos lacios, duros, empapados en aceite de coco! iiiOh el aceite de coco, lubricante eficaz del deseo!!!" ${ }^{23}$.

El lenguaje en concordancia con lo descrito es bellamente poético, fuertemente sugestivo e incitador al goce de esos cuerpos físicamente perfectos, cubiertos solo con mantas ligeras o con guayucos que solo cubren las pudendas partes; los labios rojos llenos de pasión; los senos voluminosos, temblorosos y duros, propios de la juventud, que incitan al asalto y al mordisco; pero sobretodo el estímulo del sentido primario del placer de la carne: el olfato. El aceite de coco, lubricante eficaz del deseo que hace que los nervios frente a la expectativa del goce se estiren muchos centímetros más; y que la boca se abra siempre a la posibilidad del mordisco lujurioso.

$\mathrm{Y}$ así como el poeta tiene conciencia del goce que permanentemente le ofrece la carne de la mujer, también sabe con certeza que detrás de ese goce se encuentra agazapada la muerte; ya desde su llegada a El Pájaro presiente la cercanía de la muerte que llega de la mano con el amor: " ¿Y ahora? La vida nueva, la aventura, el amor y la muerte" piensa el poeta en casa de Pablo cuando invitan a almorzar a Manuel y a Anashka. $\mathrm{Y}$ efectivamente, los amores traicioneros de Anashka y Pablo que engañan a Manuel, amante de Anashka, terminan en muerte cruel.

La muerte hace su primera aparición cuando un indígena hiere a Manuel porque se robó a la india Anashka negándose a pagar su precio; frente a lo cual, Pablo, en un arranque de furia mata al indígena. Luego de este episodio de sangre y con Manuel al borde de la muerte, Pablo y Anashka huyen para amarse, amor que no dura mucho porque pronto Anashka también abandona a Pablo y sefuga con otro. Luego, por los azares caprichosos de la vida, Pablo viaja a Manaure donde encuentra la muerte presuntamente a manos de Manuel que le pega un tiro como venganza a la traición. Pero la estela de tragedia y de dolor que deja a su paso Anashka no termina allí. Más tarde, el poeta a través de una carta que le escribe Luisito, se entera de la muerte a cuchilladas que recibió Manuel cuando quiso oponerse a que Anashka -con quien se había vuelto a unir- se escapara con un amante margariteño.

20 ZALAMEA, op. cit., p. 51.

21 Ibíd., p. 51.

22 Ibíd., p. 35.

23 Ibíd., p. 72. 
La muerte del indio, la herida de Manuel y luego su propia muerte, como la muerte de Pablo, están tejidas por los amores de Anashka, mujer sensual y provocadora de placeres supremos y muertes horrendas: "Y recordaba los labios de Anashka, frescos y rojos como la pulpa de las yguarayas, esos labios llenos de rayitas, que tienen toda la boca cruzada y tejida, como si fueran las huellas de los besos que ha dado. Anashka, redonda, redonda, redonda, como un mal pensamiento" ${ }^{24}$.

Anashka, cuerpo de mujer dadora de vida y muerte. Su desnudez es como un riachuelo donde nace y se multiplica la vida; fuente donde el hombre bebe y se embriaga de placeres hasta la muerte. Manuel siempre supo con certeza que así como Anashka llegó a su vida así se iría; de manera insospechada como es el amor y como es la muerte; llegan o se los encuentra en cualquier oscuro recodo de la vida. Manuel y Anashka se amaron al amparo del abrazo de Eros y Thanatos y en ese abrazo se confundieron amor y odio, locura y muerte: "Parecía que ella me quisiera -le cuenta Manuel al poeta- era buena, dulce y pasiva. En ocasiones fulguraba en sus ojos una llama de odio. En la noche, o en el día cuando lo ordenaba el deseo, nos amábamos furiosamente o tristemente, haciéndonos daño o con lágrimas de ternura en los ojos" ${ }^{25}$.

El amor de esta pareja como el amor de todas las parejas ideales se confunde en los extremos peligrosos que cruzan los umbrales de lo prohibido, donde el amor fácilmente se convierte en odio o en muerte. Así lo percibe Octavio Paz: "La abstención del ermitaño se resuelve en delirio solitario, la fuga de los amantes en muerte cruel" $^{26}$. Sobradas razones sustentan esta afirmación de Paz, pues todas las parejas que gozan del supremo amor terminan trágicamente: Romeo y Julieta, Calixto y Melibea, Venus y Adonis, Píramo y Tisbe, sólo por nombrar algunos casos de la literatura universal y la mitología griega.

Manuel amó tanto a Anashka, que cuando la pierde, guarda celosamente algunas de sus prendas íntimas como intento de retener y la vez recuperar el ser amado, pues estas prendas ricamente olorosas a aceite de coco le recuerdan y lo ponen en contacto con el ser perdido: "Le vi a escondidas, como si temiera que lo supiera, guardar un guayuco de Anashka, con sus camisas y vestidos. Toda su ropa iba a oler en adelante a aceite de coco $^{\prime 27}$.

Frente a la imposibilidad de alcanzar el ser deseado o ante la pérdida del mismo, el amante obsesivo recurre a prácticas de sustitución por partes del cuerpo (cabellos, uñas, etc.) o prendas que identifiquen lo amado. Recuérdese cómo Aureliano Babilonia -en Cien años de soledad, frente a la imposibilidad de poseer a Amaranta Úrsula, en las noches vaal sitiodondeella extiende su ropa interior y se satisface sexualmente en la contemplación y manipulación táctil y olorosa de sus prendas íntimas-. Frente a éstas prácticas Freud apunta que: "El sustituto del objeto sexual es, en general una parte del cuerpo... (el pie, los cabellos,-Efraín siempre guardó los cabellos de las trenzas de María-) o un objeto inanimado que mantiene una relación demostrable con la persona sexual, preferiblemente con la sexualidad de ésta (prendas de vestir, ropa interior $)^{\prime 2}$.

La ruta de amor y tragedia en Cuatro años a bordo de mí mismo se cierra con la relación triádica de Víctor, Lolita y Gabriel. Lolita engaña a Víctor con Gabriel. Fruto de estos amores, Lolita queda embarazada y cuando nace el niño, Víctor descubre que no es hijo de él, y en un momento de locura se arroja a un precipicio que da a los acantilados del mar. La muerte de Víctor deja el camino expedito para los amates transgresores.

24 Ibíd., p. 95.

25 Ibíd., p. 103.

26 PAZ, op. cit., p. 217.

27 ZALAMEA, op. cit., p. 111.

28 FREUD, op. cit., p. 139. 
Al igual que Anashka, Kuhmare, Enriqueta y todas las mujeres de la novela de Zalamea, Lolita prefigura el llanto de la tragedia. Desde el momento en que el poeta la conoce intuye los dolores que ésta encierra: "Por esa mujer algún día iba a pasar algo aquí. Desde el primer momento comprendí que estaba llena de una peligrosa sonrisa, de un terrible atractivo. Como todas las mujeres bellas incubaba el pecado en su cuerpo. Lola amable, con tu dulce nombre de dos cifras que era el disfraz de tu terrible nombre, “Dolores, Lola, mujer de peligro y de sacrificio, de aventuras y de dolor, de ternura maternal y seducción diabólica" ${ }^{29}$.

Como queda dicho, todo el lenguaje de la novela es bellamente poético, ricamente cargado de imágenes visuales, sonoras, olfativas, táctiles y gustativas; la palabra está cargada de una semántica poética donde el sentido original se trasciende y se transforma; así el negro no es negro, sino muerte; y el rojo puede ser el rojo de la sangre que se vierte en la muerte o el rojo del fuego solar que respira la sangre ardiente; el azul, puede ser el mar que es insondable e infinito en misterios o es el amor que es como el mar. Cubierta de estos misteriosos colores llega la hermosa Kuhmare a la vida del poeta en un rojo atardecer que prefigura el abrazo del amor y la muerte: "Solamente traía dentro de sí el terrible amor y el terrible deseo, asesinos" ${ }^{\prime 30}$. $\mathrm{Y}$ todo lo que rodea a Khumare, tiene sed y hambre de deseo, que prefiguran el amor y la tragedia, pues sus brazos, sus ojos, sus senos y todo su cuerpo es peligro latente.

Cuando dos seres se gustan y se atraen, la carne grita: Deseo, pasión, cópula; y a ese llamado responden el poeta y Khumare: "Como llegaba en la noche, en la noche ella se escondía y yo me escondía en la noche. Yo dentro de su cuerpo que era noche, y ella dentro de mi alma, que no era día ni mañana... ¡Oh, entonces sí que conocí el significado del valor que oculta el olor del aceite de coco! ¡El olor del aceite de coco que me hacía dos centímetros más largo cada nervio! Era ella una mujer mineral pero su sexo la convertía en una ola incesante cubierta de músculos. Cómo era de amable con su alma quimérica y mecánica que hacía los besos amargos como el hierro y levantaba -desplazándolos en todos los sentidos- mis sesenta y dos kilogramos de peso $^{31}$.

El mar, el sol, la sal, los nopales, toda la Guajira huele a deseo y muerte; obsérvese que en el baile de Enriqueta y Uribito - una negra guajira y un trabajador de las salinas- todo sugiere la cópula. El movimiento del cuerpo de ella como oleaje de mar y de lujuria; los labios húmedos y deseosos, los senos duros y vibrantes, las caderas ensanchadas como esperando algo; y el cuerpo de Uribito, magro, envarado, hecho de madera, de madera viva, ardiente y flexible; y las voces procaces de los borrachos que le gritan:

Púyala, púyala". Este pasaje es altamente sugestivo de erotismo, cargado de imágenes visuales y sensitivas. El cuerpo de Enriqueta abrasa las miradas de los hombres provocando al asalto de la posesión. El de Uribito que se envara, que es madera flexible y viva es la metáfora del miembro viril. Todas las imágenes del pasaje prefiguran el coito. Pero detrás del deseo, de la pasión, está la tragedia escondida en el licor que embriaga y destruye; no gratuitamente el poeta en medio de la embriaguez decide comprar un revólver en cuyo tambor duermen cinco balas que segarán cinco vidas: "En el tambor duermen, como en una cuna abrigada, cinco muertes incógnitas ${ }^{32}$.

Y así como Eros tiene diversas formas de manifestarse: la vida, la dicha, el placer, el goce; también Thanatos los tiene: la muerte, el desprecio, la tragedia, el dolor, el asco. Fruto del exceso de embriaguez del poeta y la seducción de Enriqueta, terminan los dos

29 ZALAMEA, op. cit., p. 180.

30 Ibíd., p. 121.

31 Ibid., p. 122.

32 Ibid., p. 127. 
en la cópula, luego de lo cual el poeta en un profundo proceso de introspección deja fluir su angustiosa sensación de arrepentimiento y asco; pero es un asco que se mezcla con goce. En este proceso, magistralmente se mezclan el deseo y el arrepentimiento, el placer de la carne y el arrepentimiento del espíritu: “¿Cómo pude hacer eso?" No lo sé. La borrachera, el cansancio, la lujuria que aparece, furiosa, ávida, con sus ojos verdes que buscan el sexo, el sexo maldito en los ángulos de los cuerpos. Y sin embargo fueron dulces sus besos, dulces y cálidos" ${ }^{\prime 33}$. Y además de asco, hay otro horror que espanta al poeta: $\mathrm{La}$ posibilidad de la prole como prolongación de la vida. El poeta siente pavor ante esta posibilidad, resultado de la carne:
Pero otra vez, aparece la obsesión que me enloqueció después de la salida de Puerto Colombia. Sí...un hijo mulato, de Enriqueta. ¡No, Señor, perdóname!... yo no quise hacerlo, me llamó ella, ella me brindaba el amor en su boca...sobre sus senos ardía la fiebre de la caricia... y en sus muslos estaba el temblor del espasmo. Señor, perdóname...no me castigues con ese castigo... ¡Que no lo vea, que no lo sepa nunca! ${ }^{34}$.

Con Cuatro años a bordo de mí mismo queda claro que a nuestra vida la gobiernan dos impulsos que siendo en todo contrarios, en todo se complementan, Eros y Thanatos; como bien lo señala Octavio Paz: "En el amor hay rivalidad, despecho, miedo, celos y finalmente odio. Ya lo dijo Catulo: El odio es indistinguible del amor" ${ }^{\prime \prime}$.

33 Ibid., p. 137.

34 Ibid., p. 137.

35 PAZ, op. cit., p. 214. 